\title{
$\beta$-Catenin Dosage Is a Critical Determinant of Tracheal Basal Cell Fate Determination
}

Heather M. Brechbuhl, Moumita Ghosh, Mary Kathryn Smith, Russell W. Smith, Bilan Li, Douglas A. Hicks, Brook B. Cole, Paul R. Reynolds, and Susan D. Reynolds

From the Department of Pediatrics, National Jewish Health, Denver, Colorado

The purpose of this study was to determine whether $\beta$-catenin regulates basal cell fate determination in the mouse trachea. Analysis of TOPGal transgene reporter activity and $\mathrm{Wnt} / \boldsymbol{\beta}$-catenin pathway gene expression suggested a role for $\beta$-catenin in basal cell proliferation and differentiation after naphthalenemediated Clara-like and ciliated cell depletion. However, these basal cell activities occurred simultaneously, limiting precise determination of the role(s) played by $\beta$-catenin. This issue was overcome by analysis of $\beta$-catenin signaling in tracheal air-liquid interface cultures. The cultures could be divided into two phases: basal cell proliferation and basal cell differentiation. A role for $\beta$-catenin in basal cell proliferation was indicated by activation of the TOPGal transgene on proliferation days 3 to 5 and by transient expression of Myc (alias c-myc). Another peak of TOPGal transgene activity was detected on differentiation days 2 to 10 and was associated with the expression of Axin 2. These results suggest a role for $\beta$-catenin in basal to ciliated and basal to Clara-like cell differentiation. Genetic stabilization of $\beta$-catenin in basal cells shortened the period of basal cell proliferation but had a minor effect on this process. Persistent $\beta$-catenin signaling regulated basal cell fate by driving the generation of ciliated cells and preventing the production of Clara-like cells. (Am J Pathol 2011, 179:367-379; DOI: 10.1016/j.ajpath.2011.03.016)

The human tracheobronchial region is characterized by a pseudostratified epithelium and the presence of smooth muscle and cartilage. ${ }^{1}$ This anatomy extends from the trachea through the first six intrapulmonary generations. Thus, the mouse trachea serves as a model for identifi- cation of pathways that regulate repair of the human tracheobronchial epithelium (TBE).

Pulse-chase and lineage tracing analyses have demonstrated that the mouse basal cell, ${ }^{1-4}$ similar to its human counterpart, ${ }^{5,6}$ serves as a progenitor for all differentiated cell types in the mouse tracheal epithelium. In the mouse trachea, parenteral naphthalene (NA) exposure depleted the secretory progenitor cell pool (termed Clara-like cells) and the ciliated cell population within 3 days. ${ }^{1}$ Basal cells, defined by the expression of keratin (K) 5, proliferated on recovery days 3 to 9 . Nascent Clara-like cells, which were defined by the expression of Clara cell secretory protein (CCSP) and nascent ciliated cells, that expressed forkhead box protein J1 (FoxJ1) or acetylated tubulin (ACT) were detected between recovery days 6 and 13. The basal cell-mediated reparative process was uniform along the proximal to distal axis of the trachea, suggesting that the basal cell progenitors were uniformly distributed. The signals that may regulate the reparative process include developmentally important pathways such as Notch, Sonic hedgehog, and Wnt/ $\beta$-catenin. ${ }^{7}$

Wnt/ $\beta$-catenin signaling waxes and wanes during lung development, suggesting that this signaling pathway regulates similar processes over time or that it mediates multiple but distinct components of organ formation. ${ }^{8-11}$ Loss- and gain-of-function studies have demonstrated that $\beta$-catenin is necessary and sufficient to alter lung branching morphogenesis. Okubo and Hogan ${ }^{10}$ demonstrated distalization of the foregut endoderm using a Lef1- $\beta$-catenin fusion protein and suggested that excess $\beta$-catenin signaling altered specification of proximal endodermal lineages. $\mathrm{Li}$ et $\mathrm{al}^{12}$ stabilized $\beta$-catenin early in lung epithelial development (approximate embryonic day 9.5) using the Nkx2.1-cre transgene and the floxed exon $3 \beta$-catenin allele. ${ }^{13}$ Cre recombinase-mediated

Supported by NIH RO1 (HL075585) and Supplement (HL075585-S1) and by the Easton Fellowship (National Jewish Health).

Accepted for publication March 31, 2011.

Supplemental material for this article can be found at http://ajp. amjpathol.org or at doi: 10.1016/j.ajpath.2011.03.016.

Address reprint requests to Susan D. Reynolds, Ph.D., Department of Pediatrics, National Jewish Health, 1400 Jackson St., Denver, CO 80206. E-mail: reynoldss@njhealth.org. 
excision of exon 3 resulted in generation of a transcriptionally active $\beta$-catenin protein that lacked the GSK3 $\beta$ phosphorylation sites. This $\beta$-catenin mutant is "stabilized." The study by Li et al ${ }^{12}$ demonstrated polyp formation in the trachea and upper airways. These polyps were devoid of ciliated and Clara-like cells, suggesting that excess $\beta$-catenin blocked generation of the tracheal secretory/ciliated lineage.

In contrast to the tracheal phenotype, stabilization of $\beta$-catenin during the pseudoglandular phase of lung development (approximate embryonic day 15.5) using the CCSP-cre transgene and the floxed exon $3 \beta$-catenin allele $^{8}$ attenuated postnatal maturation of bronchiolar Clara cells. $\beta$-Catenin stabilization did not alter Clara cell proliferation in response to NA injury but did block Clara to ciliated cell differentiation. These studies indicated that $\beta$-catenin did not drive Clara cell proliferation. However, $\beta$-catenin did play an important role in Clara cell fate determination.

Clara cell-specific knockout of $\beta$-catenin demonstrated that $\beta$-catenin was not necessary for embryonic development after the pseudoglandular stage, for postnatal maturation of bronchiolar Clara cells, or for repair of the NA-injured bronchiolar airways. ${ }^{14}$ Collectively, the gain- and loss-of-function studies indicated that a threshold level of $\beta$-catenin signaling was important for Clara and ciliated cell differentiation through the pseudoglandular stage and that an overabundance of $\beta$-catenin signaling altered Clara cell fate in the adult.

Analysis of $\beta$-catenin signaling in basal cells and its effect on basal cell fate has not been reported. We demonstrate that NA-mediated tracheobronchial injury results in transient $\beta$-catenin stabilization during the period of basal cell proliferation/differentiation. This observation led us to hypothesize that $\beta$-catenin serves as a signal that toggles the basal cell life cycle between cell division and generation of differentiated ciliated and Clara-like cells. Analysis of the $\beta$-catenin reporter transgene TOPGal ${ }^{15}$ demonstrated that $\beta$-catenin stabilization was associated with basal cell proliferation and differentiation in tracheal epithelial cell cultures. Genetic stabilization of $\beta$-catenin demonstrated that $\beta$-catenin did not promote basal cell proliferation. However, $\beta$-catenin down-regulation was required for generation of appropriate numbers of ciliated cells and for basal to secretory cell differentiation. We conclude that $\beta$-catenin is a critical determinant of basal cell fate determination in the tracheal epithelium.

\section{Materials and Methods}

\section{Animal Strains}

All the animals were cared for and treated according to procedures approved by the National Jewish Health Institutional Animal Care and Use Committee. All the experiments used adult mice 6 to 8 weeks old. TOPGalC57BI/6 congenic (TOPGal-B6) mice were generated by backcrossing CD1-TopGal ${ }^{15}$ mice with C57BI/6 mice for 10 generations. C57BI/6 mice were used for in vivo gene expression. Air-liquid interface (ALI) cultures were estab- lished from TOPGal-B6 mice for X-Gal reporting experiments. Fvb/n mice were used for in vitro gene expression analysis. K14/rtTA/TRE-cre/DE3 mice were generated by breeding transgenic mice harboring the K14-reverse tetracycline $(\mathrm{T})$ transactivator (K14-rtTA), ${ }^{16} \mathrm{~T}$ response element-cre recombinase trangenic mice (TRE-cre), ${ }^{17}$ to mice homozygous for the floxed $\beta$-catenin exon 3 allele (DE3). ${ }^{13}$ Bitransgenic mice that were homozygous for the floxed allele were used to establish the ALI cultures used for $\beta$-catenin stabilization experiments.

\section{NA Exposures}

Dose-response experiments were used to determine the dose of NA needed to cause $95 \%$ depletion of Clara cells on posttreatment day 3 in TOPGal-B6 mice. This dose was $275 \mathrm{mg} / \mathrm{kg}$. NA was delivered i.p. as previously reported. ${ }^{1}$ Mice were weighed daily. Survival was $>95 \%$. Tissue was recovered for histologic and gene expression analyses on recovery days $3,6,9$, and 13 .

\section{Primary Tracheal ALI Cultures}

ALI cultures were established based on the method of You et $\mathrm{al}^{18}$ using tracheae from 6- to 8-week-old mice. Tracheae were carefully cleaned of excess tissue and glands by blunt dissection. Cells were recovered by digestion with $0.15 \%$ pronase (from Streptomyces griseus) in Ham's F-12 supplemented with L-glutamine and $5 \%$ penicillin/streptomycin. Digestion was overnight at $4^{\circ} \mathrm{C}$. The protease was inactivated by the addition of $10 \%$ fetal bovine serum. Cells were removed from the trachea by gentle agitation, were pelleted at $300 \times g$, and were plated in Dulbecco's modified Eagle's medium $/ 5 \%$ penicillin/streptomycin/10\% fetal bovine serum for 3 hours at $37^{\circ} \mathrm{C}$ with $5 \% \mathrm{CO}_{2}$ to remove macrophages and fibroblasts. The cells were pelleted at $300 \times g$ and were plated in collagen I-coated Transwells (Corning Inc., Corning, NY) at a density of $1.0 \times 10^{5} \mathrm{cells} / \mathrm{cm}^{2}$.

The proliferation phase of ALI cultures is defined as the period when cells are proliferating and creating a polarized epithelium. During the proliferation phase, cultures were grown in MTEC+, Dulbecco's modified Eagle's medium/F-12 (1:1) (Gibco, Grand Island, NY) supplemented with $2 \mathrm{mmol} / \mathrm{L}$ L-glutamine (Mediatech Inc., Manassas, VA), $0.25 \mu \mathrm{g} / \mathrm{mL}$ of amphotericin B (Sigma-Aldrich Corp., St. Louis, MO), 5\% penicillin/ streptomycin, $7.5 \% \mathrm{NaHCO}_{3}, 5 \%$ fetal bovine serum (HyClone, Logan, UT), insulin-transferrin-selenium (Gibco), $10 \mu \mathrm{g} / \mathrm{mL}$ of insulin, $5 \mu \mathrm{g} / \mathrm{mL}$ of transferrin, 5 $\mu \mathrm{g} / \mathrm{mL}$ of selenite, $0.1 \mathrm{mg} / \mathrm{mL}$ of cholera toxin (SigmaAldrich Corp.), $0.1 \mu \mathrm{g} / \mathrm{mL}$ epithelial growth factor (BD Biosciences, Franklin Lakes, NJ), $25 \mathrm{ng} / \mathrm{mL}$ of bovine pituitary extract (Gibco), $0.03 \mathrm{mg} / \mathrm{mL}$ of hydrocortisone (MP Biomedicals, Solon, $\mathrm{OH}$ ), and $50 \mathrm{nmol} / \mathrm{L}$ retinoic acid (Sigma-Aldrich Corp.). Proliferation day 0 is defined as the day the cells are seeded. Transepithelial resistance is measured beginning on proliferation day 4. Cultures that reach $>330 \Omega-\mathrm{cm}^{2}$ are fed proliferation media and are cultured for 1 additional day. At this time, transepithelial resistance averaged $2000 \Omega-\mathrm{cm}^{2}$. 


\section{Gene Expression Analysis}

Tracheal RNA was isolated for gene expression analysis according to previously described methods. ${ }^{1}$ Tracheae were isolated as indicated previously herein. Tissue was stored in RNAlater (Ambion, Foster City, CA) at $4^{\circ} \mathrm{C}$ overnight and at $-80^{\circ} \mathrm{C}$ until RNA isolation. RNA from ALI cultures was isolated for gene expression using the Absolutely RNA microprep kit (Agilent Technologies, La Jolla, CA) according to manufacturer protocols. Pools of RNA from normal tracheae were used as a calibrator for tracheal and ALI gene expression. Real-time analysis of gene expression was completed as previously reported. ${ }^{1}$ Assays on demand used in this study were purchased from Applied Biosystems (Carlsbad, CA) and included CCSP (Mm00442046_m1), $\beta$-glucuronidase (Mm00446953_m1), FoxJ1 (Mm00807215_m1), Lef1 (Mm00550265_m1), Myc (alias c-myc) (Mm00487803_m1), Tcf7 (Mm00493445_m1), K5 (Mm00503549_m1), Axin 2 (Mm00443610_m1), and Plunc (Mm00465064_m1). Standard reagents and protocols from Applied Biosystems were used. Relative gene expression was calculated using the delta-delta cycle threshold method. ${ }^{19}$

\section{Immunofluorescence and Histologic Staining}

Tissue staining was as previously reported. ${ }^{1} \mathrm{ALI}$ cultures were fixed for 20 minutes at $4^{\circ} \mathrm{C}$ with $3.0 \%$ sucrose/3.2\% paraformaldehyde/1X PBS solution. Membranes were rinsed with $1 \mathrm{X}$ PBS, removed from the plastic insert, placed in a 24-well plate, and stained using standard methods and previously validated antibodies. ${ }^{1,8}$ Images were captured using a Zeiss AxioVision microscope (Carl Zeiss Microlmaging $\mathrm{GmbH}$, Jena, Germany) using 11 steps on the Z-axis and the extended focus function.

\section{Morphometry}

Regions of interest were identified in the DAPI channel followed by imaging in the red or green channels. At least three images were acquired at $\times 200$ or $\times 400$. Cells were defined by the presence of a DAPI-stained nucleus. The number of nuclei per field was determined and was set as the denominator. The number of cells expressing the marker of interest in each field was determined and was set as the numerator. Experiments were repeated up to three times and included a minimum of three replicates. Data are presented as mean \pm SEM.

\section{Western Blot}

Tracheae were collected into ice-cold radioimmunoprecipitation assay buffer [1\% Triton X-100 (Roche Diagnostics $\mathrm{GmbH}$, Mannheim, Germany), $0.35 \mathrm{~mol} / \mathrm{L}$ SDS, 0.15 $\mathrm{mol} / \mathrm{L} \mathrm{NaCl}$, and $0.05 \mathrm{~mol} / \mathrm{L}$ Tris $(\mathrm{pH} \mathrm{8})]$ with $1 \mathrm{X}$ SigmaFast protease inhibitor tablets (\#S8820; Sigma-Aldrich, St Louis, MO), 1X Halt phosphatase inhibitor cocktail (\#78420; Thermo Scientific, Waltham, MA), and $1 \mathrm{mmol} / \mathrm{L}$ phenylmethanesulfonyl fluoride (\#78830; Sigma-Aldrich). Tracheae were homogenized by alternating bead-beating for 60 seconds at 4000 rpm (Tomy Micro Smash
MS-100, CS Bio Co, Menlo Park, CA) and incubating on ice for 5 minutes. Homogenates were centrifuged at 2000 rpm at $4^{\circ} \mathrm{C}$ for 5 minutes, and supernatants were recovered for protein analysis. Twenty micrograms of sample was added to each lane of BioRad Criterion XT precast $4 \%$ to $12 \%$ Bis-Tris gels (BioRad Laboratories, Hercules, $\mathrm{CA}$ ), and electrophoresis and transfer (polyvinylidene difluoride membranes) were completed on BioRad's Criterion gel box system according to manufacturer protocols. Membranes were blocked overnight at $4^{\circ} \mathrm{C}$ in Odyssey blocking buffer (Li-Cor Biosciences, Lincoln, NE). Primary antibodies were added overnight at $4^{\circ} \mathrm{C}$ at $1: 1000$ in Odyssey blocking buffer with $0.2 \%$ Tween 20 (Roche Diagnostics $\mathrm{GmbH}$ ). Membranes were washed three times for 10 minutes at room temperature in $\mathrm{PBS} / 0.1 \%$ Tween 20. Secondary antibodies were applied 1:20,000 in Odyssey blocking buffer with $0.2 \%$ Tween 20 and $0.01 \%$ SDS for 1 hour in the dark. Membranes were washed as described previously and then were scanned using the Li-Cor Odyssey imager. The primary antibodies used in this study were mouse monoclonal anti-actin (C-2) (\#sc-8432; Santa Cruz Biotechnology, Santa Cruz, $\mathrm{CA}$ ), rabbit anti- $\beta$-catenin (amino-terminal) (\#9581; Cell Signaling Technology, Danvers, MA), and mouse anti- $\beta$ catenin (C-terminal) (\#610154; BD Biosciences Pharmingen, San Diego, CA). The secondary antibodies used were goat anti-mouse IR 800 (\#926-32210; Li-Cor) and goat anti-rabbit IR 680 (\#926-3222; Li-Cor).

\section{Statistical Analysis}

Analysis of variance with Tukey comparisons and 2-way analysis of variance with Bonferroni comparisons were calculated using GraphPad Prism version 5 (GraphPad Software Inc., San Diego, CA). A $P<0.05$ was considered statistically significant.

\section{Results}

\section{NA Injury in C57BI/6 Strain Mice}

The goal of this study was to evaluate $\beta$-catenin-dependent gene expression in steady state and in response to NA-mediated injury. To benchmark this analysis to previous studies, the NA dose response and injury and repair patterns were documented. A previous analysis using female Fvb/n mice demonstrated that NA exposure resulted in depletion of tracheal Clara-like and ciliated cells. ${ }^{1}$ The abundance of CCSP mRNA, a Clara-like cell marker, was $5 \%$ of control levels on recovery day 3 and returned to $80 \%$ of control levels on recovery day 13 . Preliminary analysis demonstrated that the original TOPGal-CD1 strain $^{15}$ was insensitive to NA relative to the $\mathrm{Fvb} / \mathrm{n}$ strain mice. Minimal injury was observed at an NA dose of 325 to $350 \mathrm{mg} / \mathrm{kg}$ body weight, and the lung epithelial injury pattern was inconsistent (data not shown). In contrast, an NA dose-response analysis in TOPGal (C567BI/6 congenic, TOPGal-B6) mice demonstrated that $275 \mathrm{mg} / \mathrm{kg}$ of NA resulted in a $97 \%$ decrease in CCSP mRNA abundance on recovery day 3 and a return to $85 \%$ of control on recovery day 9 (see Supple- 

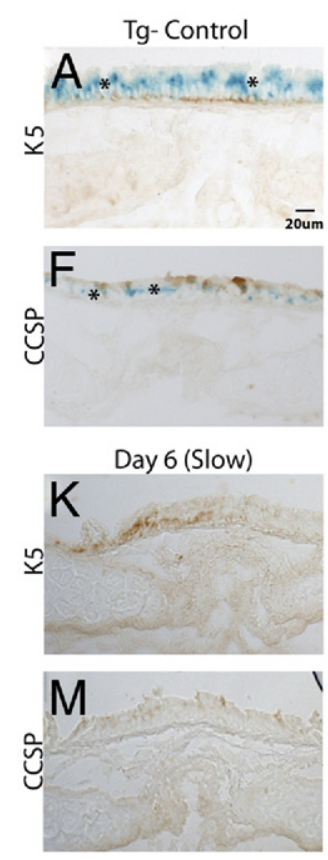

$\mathrm{Tg}+$ Control
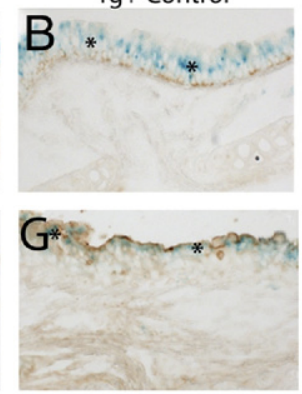

Day 6 (Rapid)
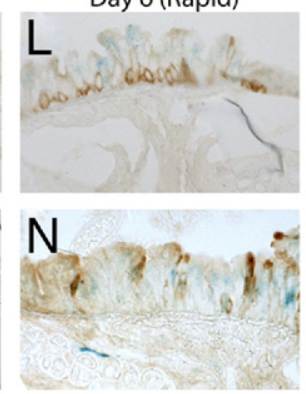

Day 3
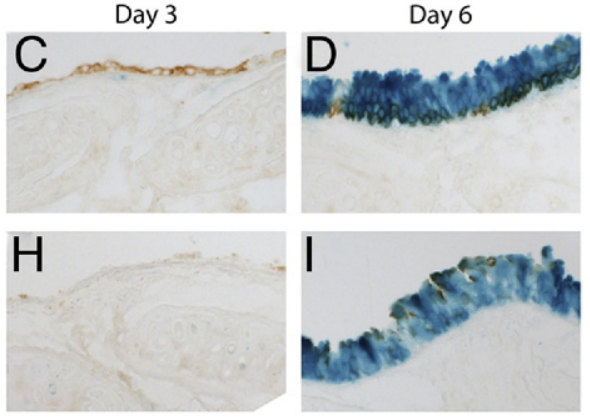

Figure 1. $\beta$-Catenin stabilization in NA-treated TOPGal mice. Male TOPGal (B6 congenic) mice were treated with $275 \mathrm{mg} / \mathrm{kg}$ of NA and recovered at 2 to 13 days Transgene activity (blue) and basal $(\mathrm{K} 5+)$ or secretory $(\mathrm{CCSP}+)$ cell recovery (brown) were assessed over time. $\mathbf{A}, \mathbf{B}, \mathbf{F}$, and $\mathbf{G}$ : Untreated controls. Transgene $(\mathrm{Tg})$ negative $(\mathbf{A}$ and $\mathbf{F})$ and positive $(\mathbf{B}$ and $\mathbf{G})$ tracheal sections. Endogenous eukaryotic $\beta$-gal staining is indicated by asterisks. C-E and $\mathbf{H}-\mathbf{J}$ : Recovery time points. $\mathbf{C}$ and $\mathbf{H}$ : Three days after NA. $\mathbf{D}$ and I: Six days after NA. $\mathbf{E}$ and $\mathbf{J}$ : Thirteen days after NA. K-N: NA-induced injury results in variable repair on day 6. $\mathbf{K}$ and $\mathbf{M}$ : Slow recovery. $\mathbf{L}$ and $\mathbf{N}$ : Rapid recovery. mental Figure S1A at http://ajp.amjpathol.org). This analysis detected more variation in CCSP mRNA abundance on recovery days 6 and 9 than previously reported for $\mathrm{Fvb} / \mathrm{n}$ mice. Body weight change paralleled changes in CCSP mRNA abundance (see Supplemental Figure S1B at http://ajp.amjpathol.org). A sexually dimorphic response to NA treatment was not observed for the C57BI/6 background (see Supplemental Figure S1C at http://ajp. amjpathol.org).

\section{Trachea Morphology in NA-Treated Mice}

The number and distribution of basal and Clara-like cells in the tracheae of steady state and NA-injured TOPGal-B6 mice was assessed by histologic analysis. A single layer of $\mathrm{K} 5+$ basal cells was positioned adjacent to the basement membrane (Figure 1, A and B). Rare K5+ cells co-expressed K14 (data not shown). Basal cell shape varied from tall/pyramidal to short/squamous. This variation did not differ between wild-type and transgenic positive (data not shown). Clara-like cells expressed CCSP and exhibited an apical surface that projected into the airway lumen (Figure 1, F and G). Columnar and cuboidal Clara-like cells were noted, and the frequency of these morphologic variants did not vary between wild type and transgenic positive. Three days after NA administration, the epithelium was severely disrupted. Most regions had an intact basal cell layer containing squamated K5+ cells (Figure 1C). Clara-like cells were absent (Figure $1 \mathrm{H}$ ), as were ciliated cells (data not shown).

In most animals, epithelial repair was evident by recovery day 6 , but three subpatterns were noted. An intermediate repair pattern was characterized by increased density of basal cells (Figure 1D), with some areas of basal cell hyperplasia. Moderate restoration of Clara-like cells was detected (Figure 1I). A slower repair process was noted in $\sim 25 \%$ of animals. This "slow repair" was typified by a broken line of basal cells and some regions that were devoid of basal cells (Figure $1 \mathrm{~K}$ ). Clara-like cells were not detected on recovery day 6 in the slow repair group (Figure $1 \mathrm{M}$ ). The remaining 25\% of animals underwent a "rapid repair" process in which numerous Claralike cells were detected on recovery day 6 (Figure $1 \mathrm{~N}$ ). These differences in repair kinetics could not be attributed to the level of injury because depletion of CCSP mRNA and body weight loss on recovery day 3 was similar for all groups (see Supplemental Figure S1 at http://ajp.amjpathol.org; data not shown). Regardless of the repair pattern, the epithelium regained much of its pseudostratified appearance by recovery day 13 and was populated by basal (Figure 1E), Clara-like (Figure $1 \mathrm{~J})$, and ciliated (data not shown) cells.

\section{$\beta$-Galactosidase Expression in Control C57BI/6 Mice}

Analysis of transgene-negative C57BI/6 mice demonstrated a high level of endogenous (eukaryotic) $\beta$-galactosidase $(\beta$-gal) activity in the normal tracheal epithelium (Figure 1, A and F). This $\beta$-gal activity persisted despite careful adjustment of the buffer $\mathrm{pH}^{20}$ The eukaryotic $\beta$-gal activity was limited to a "belt-like" staining pattern in CCSP + Clara-like cells (compare Figure 1, A and F). An independent flow cytometry analysis used a fluorescent $\beta$-gal reporter and demonstrated that cells from control C57BI/6 mice contained a high level of $\beta$-gal activity. This activity could not be inhibited by chloroquine diphosphate and suggested that the enzyme was lysosomal. Other strains, such as Fvb/n, also demonstrated this high level of endogenous $\beta$-gal activity (data not shown). Therefore, it is important to evaluate individual strains for endogenous $\beta$-gal activity when using a $\beta$-gal reporter. 


\section{$\beta$-Catenin-Dependent Gene Expression in Control and NA-Treated TOPGal-B6 Mice}

Control TOPGal-B6 transgene-positive mice exhibited a $\beta$-gal pattern that was indistinguishable from that observed in control C57BI/6 wild-type mice (compare Figure 1, $A$ and $F$, with Figure 1, B and $G$ ). Consequently, we were unable to use the TOPGal reporter to evaluate $\beta$-catenin-dependent gene expression in the tracheal epithelium under steady state conditions.

NA treatment resulted in ablation of Clara-like cells on recovery day 3 and complete loss of the steady state $\beta$-gal staining pattern (Figure 1, $\mathrm{C}$ and $\mathrm{H}$ ). The absence of $\beta$-gal activity on recovery day 3 indicated that any subsequent changes in $\beta$-gal activity could be attributed to reexpression of the $\beta$-gal reporter in previously negative cells. On recovery day 6 , intense $\beta$-gal activity was detected in mice exhibiting intermediate repair kinetics (Figure 1, D and I). This activity was $\mathrm{pH}$ dependent (data not shown), indicating that it was due to expression of the prokaryotic $\beta$-gal reporter. On recovery day $6, \beta$-gal activity was detected throughout the epithelial layer and was present in the previously negative $\mathrm{K} 5+$ basal cells. $\beta$-Gal activity was also detected in nascent CCSP + cells. Transgene activity was not detected in glandular structures (data not shown) or in nonepithelial tissues. Mice exhibiting slow repair were negative for $\beta$-gal activity on recovery day 6 (Figure $1, \mathrm{~K}$ and $\mathrm{M}$ ), and mice undergoing rapid repair exhibited a $\beta$-gal pattern that was similar to that of control on recovery day 6 (Figure $1, L$ and $N$ ). On recovery day 13 , all the mice exhibited the control $\beta$-gal activity pattern (Figure 1, E and J). This analysis indicated that $\beta$-catenin-dependent gene expression was transiently activated in basal cells after NA-mediated Claralike and ciliated cell depletion.

\section{Expression of WNT/ $\beta$-Catenin Pathway Target Genes after NA Injury}

TOPGal transgene activation implied expression of $\beta$-catenin target genes. Genes in this analysis were selected on the basis of a preliminary survey of $86 \mathrm{WNT} / \beta$ catenin pathway genes (SuperArray; data not shown), which demonstrated differential expression of Lef1, TCF7, Myc, and Axin 2 after NA treatment. Transcript abundance in total tracheal RNA from control C57BI/6 mice and those exposed to $275 \mathrm{mg} / \mathrm{kg}$ of NA and recovered for 5 to 9 days was quantified by real-time RT-PCR. Lef1 mRNA decreased fourfold between control and recovery days 5 and 6 and returned to control levels on recovery days 7 to 9 (Figure 2A). TCF7 mRNA was also detected in control RNA and was depleted approximately twofold on recovery days 5 to 9 (Figure 2B). TCF7 mRNA levels were significantly different on recovery days 5,7 , and 8. Differences in the Lef1 and TCF7 gene expression patterns suggested a complex and variable role for $\beta$-catenin in the repair process.

In contrast to the $\beta$-catenin interaction partner results, Myc mRNA abundance increased 1.7 -fold on recovery day 5 (Figure 2C). This increase was transient, and Myc
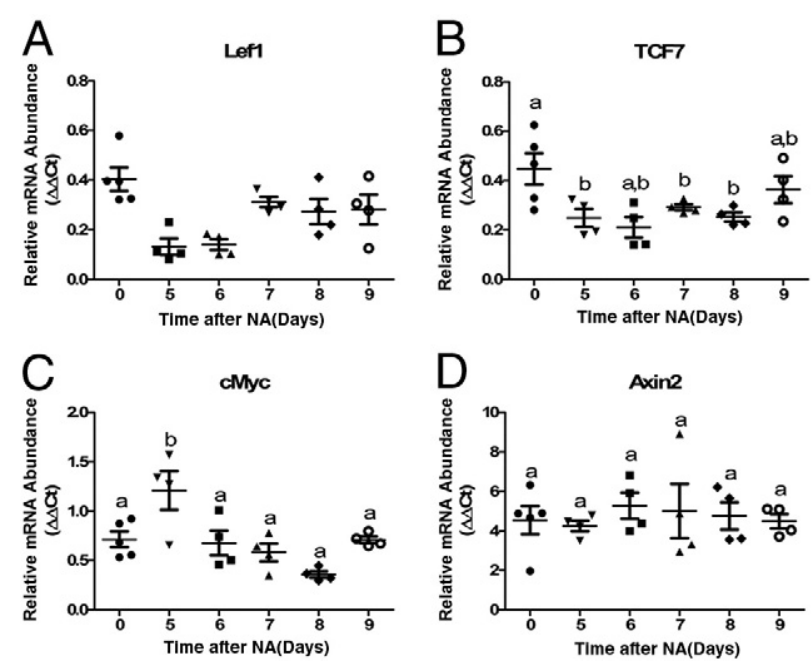

Figure 2. WNT pathway gene expression after NA administration. Expression of WNT/ $\beta$-catenin target genes was assayed during the period of TopGal transgene activity. Control C57/Bl6 mice were treated with $275 \mathrm{mg} / \mathrm{kg}$ of NA and recovered at 5 to 9 days. WNT pathway gene expression was evaluated by real-time RT-PCR. Data are presented as mean \pm SEM. Columns with nonidentical superscript letters are significantly different $(P<0.05)$ as determined by analysis of variance using the Tukey postcomparison test. A: Lef1. B: TCF7. C: Myc. D: Axin2.

mRNA abundance decreased to control levels on recovery days 6 to 9 . Because Myc expression is most commonly associated with changes in mitotic state, these data suggest that $\beta$-catenin-dependent gene expression plays a role in proliferation.

Significant differences in Axin $2 \mathrm{mRNA}$, a negative regulator of the $W n t / \beta$-catenin pathway, were not detected (Figure 2D). Given the complexity of the in vivo injury/repair system ${ }^{1}$ and the variability in the rates of recovery between animals (Figure 1), small changes in mRNA levels, particularly mRNAs that oscillate, ${ }^{21,22}$ may be difficult to detect using whole tissue preparations. Overall, changes in the abundance of Lef1, TCF7, and Myc suggested that $\beta$-catenin target genes were expressed in the steady state and that these genes were reactivated in response to NA injury. However, the high level of $\beta$-gal activity in steady state Clara-like cells and simultaneous proliferation and differentiation after NA injury demanded cautious interpretation of these results.

\section{Separation of Proliferation and Differentiation in ALI Cultures}

To evaluate roles for $\beta$-catenin in epithelial repair, this process was reduced to its component parts, basal cell proliferation and basal cell differentiation. These processes were evaluated in primary cultures of tracheal epithelial cells, termed ALI cultures. ALI cultures were first evaluated for their ability to recapitulate key aspects of the NA injury and repair process. Histologic analysis was used to determine the cell types responsible for establishment of the ALI culture. Cytospin preparations from 15 strains of mice were evaluated for representation of basal cells ( $\mathrm{K} 5+$ and/or $\mathrm{K} 14+)$, Clara-like cells (CCSP +$)$, and ciliated cells (ACT+). This analysis dem- 


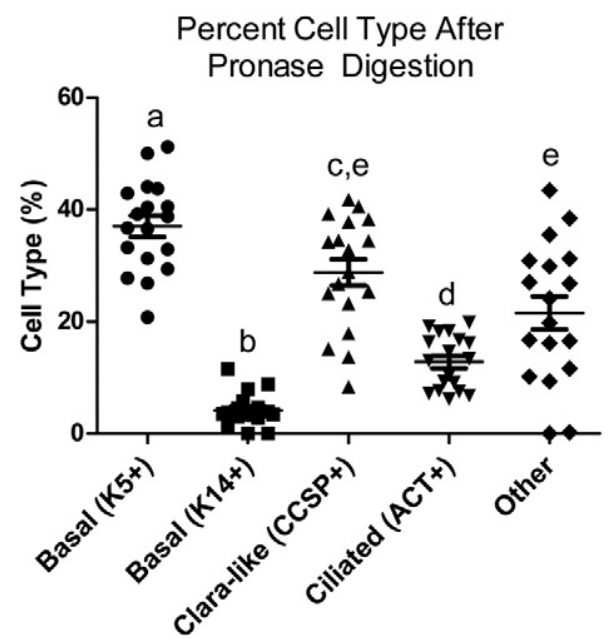

Figure 3. Representation of cell types recovered from tracheae by pronase digestion. Immunofluorescence staining of cytospin preparations was used to determine the representation of cells recovered after pronase digestion of the trachea. Fifteen different strains of mice were analyzed. The cell type mean values centered around the following: K5+ basal cells, 37\%; K14+ basal cells, 4.2\%; CCSP + Clara-like cells, 28.8\%; ACT + ciliated cells, $12.8 \%$; and other cells (not expressing any of the assayed markers), 21.5\%. Data are presented as mean \pm SEM. Columns with nonidentical superscript letters are significantly different $(P<0.05)$ as determined by analysis of variance using the Tukey postcomparison test.

onstrated that $37 \%$ of cells recovered by pronase digestion were basal cells (Figure 3 ). Of this population, 37\% were $\mathrm{K} 5+/ \mathrm{K} 14-$ and $4.2 \%$ were $\mathrm{K} 14+$. Significant differences were not detected among mouse strains. Claralike cells were $28.8 \%$ and ciliated cells were $12.8 \%$ of the pronase cell preparation. These three cell types accounted for $78.5 \%$ of nucleated cells.

Proliferation and differentiation occurred simultaneously in vivo, and the repair rate was variable among individuals (Figure 1). Thus, we determined whether proliferation and differentiation could be separated in ALI cultures. Cell proliferation was evaluated by pulse labeling with bromodeoxyuridine (BrdU) (Figure 4). The mitotic index was $78 \%$ on ALI day 0 , decreased to $~ 30 \%$ on ALI day 2 , and was $2 \%$ to $5 \%$ on ALI days 4 to 10 . These data indicate that mitotic activity decreases precipitously after the shift to growth factor-reduced medium and establishment of the ALI. These data are consistent with previous reports ${ }^{18}$ and indicate that the submerged culture period through ALI day 2 could be termed the proliferation stage.

During the proliferation phase, basal cells, defined by $\mathrm{K} 5$, accounted for $>98 \%$ of cells in culture (see Supplemental Figures S2 and S3 at http://ajp.amjpathol. org). These data, and co-localization of BrdU and K5 (data not shown), indicate that basal cell proliferation drives establishment of the ALI culture. When the culture media was switched to promote differentiation, there was a 24- to 48-hour period during which basal cells were the dominant cell type (see Supplemental Figures S2, A-D, and S3, A-D, at http://ajp.amjpathol.org). On ALI day 3, ciliated cells begin to appear (see Supplemental Figure S3D at $h t t p: / / a j p . a m j p a t h o l . o r g)$. This cell type increased in number through ALI day 10 (see Supplemental Figure S3, D-H, at http://ajp.amjpathol.org). Ciliated cell fre- quency did not vary after ALI day 10 (see Supplemental Figure S3, G and $\mathrm{H}$, at http://ajp.amjpathol.org). Clara-like cells were first detected on ALI day 6 (see Supplemental Figure S3E at $h$ ttp://ajp.amjpathol.org) but were not highly prevalent until ALI days 10 to 12 (see Supplemental Figure S3, F and G, at http://ajp.amjpathol.org). Additional analysis demonstrated that the abundance of Clara-like cells peaked on ALI day 10 and that representation of this cell type decreased through ALI day 20 (data not shown). Thus, ciliated cells differentiated first and were followed by Clara-like cells.

Analysis of nine $\mathrm{ALI}$ experiments indicated that the kinetics of proliferation and differentiation were consistent among different cultures and that these variables were independent of mouse strain. These data are in agreement with previous reports ${ }^{18}$ and indicated that ALI days 4 to 12 could be termed the differentiation stage. These data, combined with previous lineage tracing analysis, ${ }^{23}$ demonstrated that the ALI culture system faithfully represented the differentiated cell types generated as part of the in vivo repair process (basal, ciliated, and Clara-like), the order in which they were regenerated (basal then ciliated then Clara-like), and the source of differentiated cells (direct basal to ciliated, basal to Clara-like, and Clara-like to ciliated).

\section{Gene Expression Changes in the ALI System Parallel Those Associated with NA-Mediated Injury and Repair}

To determine whether the ALI model system recapitulated gene expression changes associated with NA-mediated injury and subsequent repair, expression of cell type-specific mRNAs was compared in control and NAtreated tracheal tissue and in ALI cultures. In vivo, expression of $\mathrm{K} 5$ increased after NA exposure, but this increase was not significantly different from control at any recovery time point (Figure 5A). A similar pattern was noted in ALI cultures with the exception that K5 mRNA abundance was significantly increased relative to control on ALI day 1 (Figure 5B). This increased gene expression was as-

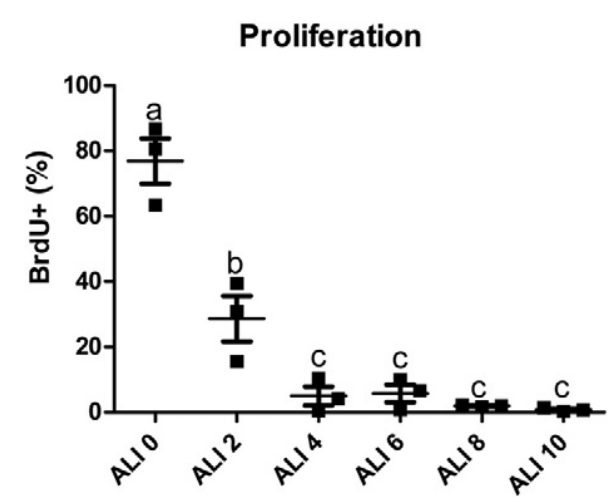

Figure 4. Proliferation in ALI cultures. Proliferation in ALI cultures was evaluated by pulse labeling with $\operatorname{BrdU}(10 \mu \mathrm{mol} / \mathrm{L})$. Cultures were fixed on ALI days 0 to 10 and were evaluated for BrdU labeling using immunofluorescence. Data are presented as mean \pm SEM. Columns with nonidentical superscript letters are significantly different $(P<0.05)$ as determined by analysis of variance using the Tukey postcomparison test. 

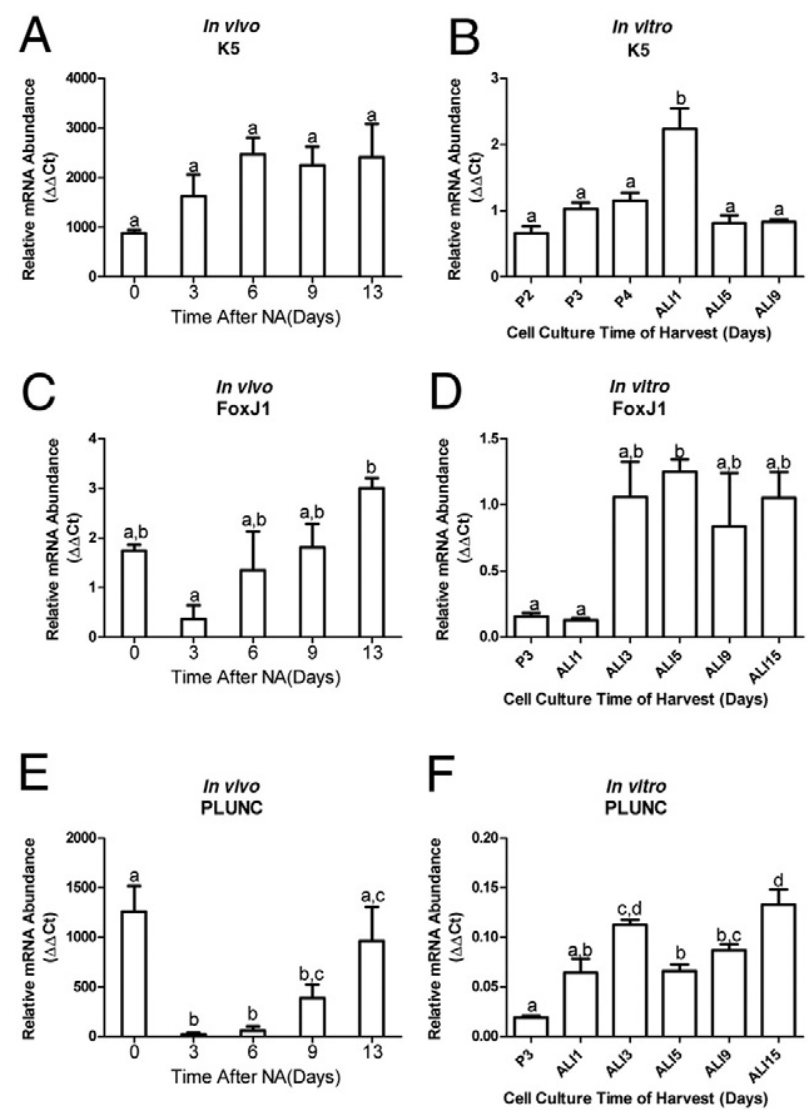

Figure 5. Comparison of cell type-specific marker gene expression in vivo and in vitro. A, C, and E: Fvb/n mice were treated with $300 \mathrm{mg} / \mathrm{kg}$ of NA and recovered at 3 to 13 days. A: Basal cell marker, K5. C: Ciliated cell marker, FoxJ1. E: Clara-like cell marker, PLUNC. B, D, and F: ALI cultures were established from $\mathrm{Fvb} / \mathrm{n}$ mice and were collected for gene expression on proliferation days (P2 to P4) and on differentiation days (ALI1 to ALI15). B: Basal cell marker, K5. D: Ciliated cell marker, FoxJ1. F: Clara-like cell marker, PLUNC. Data are presented as mean \pm SEM. Columns with nonidentical superscript letters are significantly different $(P<0.05)$ as determined by analysis of variance using the Tukey postcomparison test

sociated with a change in cell shape and the organization of cytoplasmic K5 (see Supplemental Figure S2, D and E, at http://ajp.amjpathol.org).

As previously reported, ${ }^{1}$ FoxJ1 mRNA, which encodes a ciliated cell-specific transcription factor, was severely reduced after NA treatment, and its abundance increased rapidly after day 3 (Figure 5C). In ALI cultures, the pattern of FoxJ1 mRNA abundance (Figure 5D) paralleled histologic detection of cilia (see Supplemental Figure S3D at http://ajp.amjpathol.org). The Clara-like cell marker PLUNC was severely depleted after NA injury and rebounded on recovery days 9 to 13 (Figure 5E). In ALI cultures, PLUNC exhibited a biphasic expression pattern, with peaks on ALI days 3 and 15 (Figure 5F). Previous analysis indicated that the early peak correlated with re-expression of the Clara-like marker CCSP by rare Clara-like cells that seeded the culture. ${ }^{23}$ In contrast, the late peak coincided with basal to Clara-like cell differentiation. These data indicated that ALI cultures separated basal to ciliated cell differentiation from basal to Claralike cell differentiation.

\section{$\beta$-Catenin Is Stabilized during the Late Proliferation Stage and throughout the Differentiation Phase in Vitro}

Because the ALI model allowed temporal separation of proliferation and differentiation, expression of the TOPGal transgene was evaluated in ALI cultures generated from TOPGal-B6 tracheal cells. X-Gal staining was used to detect $\beta$-gal activity (see Supplemental Figure S4, A-J, at http://ajp.amjpathol.org). $\beta$-Gal enzyme activity was not detected in cultures derived from transgene-negative mice (see Supplemental Figure S4K at http://ajp.amjpathol.org).

Analysis of TOPGal-B6 ALI cultures identified a dynamic pattern of $\beta$-catenin signaling during the proliferation phase (Figure 6). Less than $10 \%$ of cells were X-Gal+ on proliferation day 2 (see Supplemental Figure S4A at http://ajp.amjpathol. org). Transgene activity increased to include $\sim 40 \%$ of cells on day 4 and $\sim 80 \%$ of cells on day 5 (see Supplemental Figure S4, C and D, at http://ajp.amjpathol.org). Staining intensity increased between days 3 and 4, suggesting accumulation of the reporter enzyme. This activity correlated with establishment of a confluent monolayer and polarization of the epithelium. These data suggest a role for $\beta$-catenin in the regulation of basal cell proliferation.

TOPGal transgene activity was diminished on ALI day 0 (see Supplemental Figure S4E at http://ajp.amjpathol.org), when the cultures were switched to growth factor-deficient medium. The diffuse X-Gal staining on ALI day 0 may indicate turnover of the reporter enzyme. Transgene activity resumed as the cultures progressed toward ciliated or Clara-like cell differentiation. On ALI day 2, 95\% of cells were X-Gal+ (see Supplemental Figure S4F at http://ajp. amjpathol.org). On ALI days 4 to 10, 99\% of cells were positive for X-Gal (see Supplemental Figure S4, G-J, at http://ajp.amjpathol.org). The X-Gal reaction product did not co-localize with a specific cell type (data not shown). This analysis supports a role for $\beta$-catenin in basal cell differentiation.

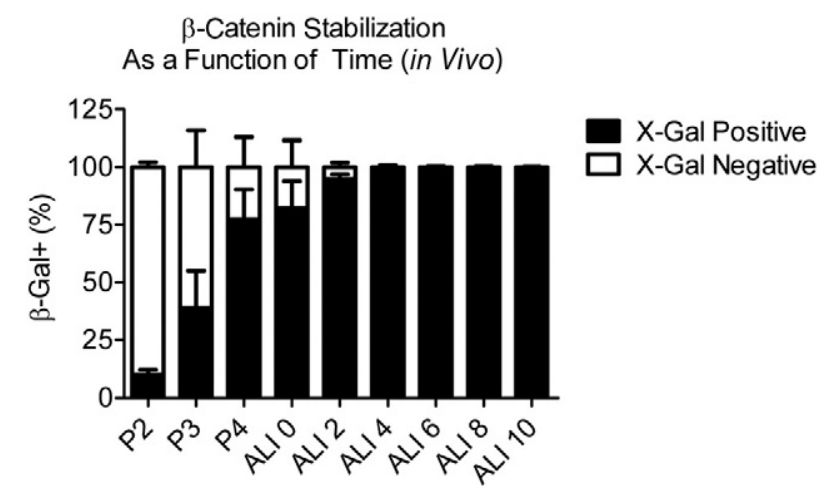

Figure 6. $\beta$-Catenin stabilization in TopGal-B6 ALI. ALI cultures were established from TopGal-B6 mice. $\beta$-Catenin stabilization was determined throughout the proliferation (P2 to P4) and differentiation (ALI0 to ALI10) days by X-Gal staining. The frequency of cells that expressed the $\beta$-gal reporter was determined in five randomly selected regions from each time point. The percentage of cells positive (black) or negative (white) for the reporter is reported. Data are presented as mean \pm SEM. 

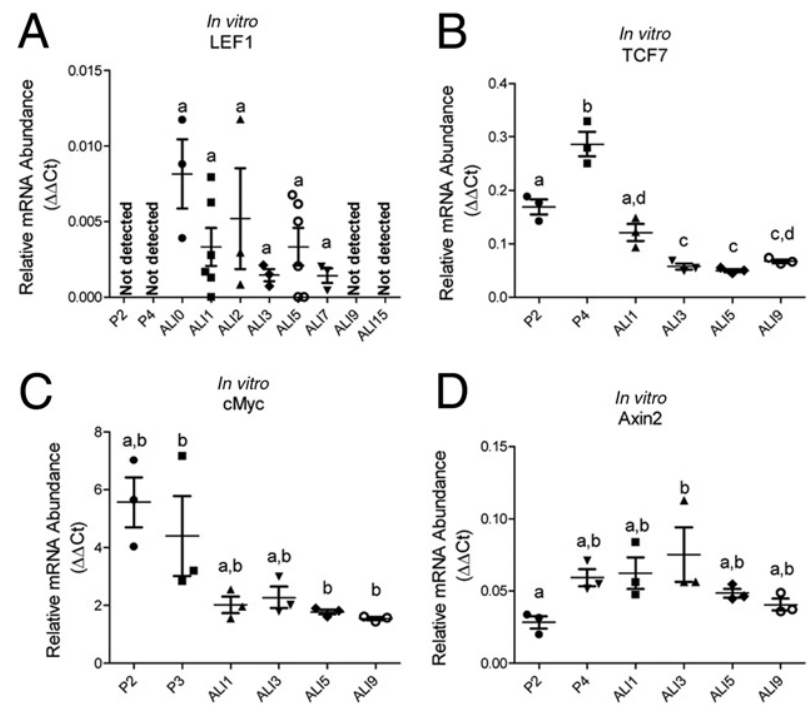

Figure 7. WNT pathway gene expression in ALI cultures. Expression of WNT/ $\beta$-catenin target genes was assayed by real-time RT-PCR during the period of TopGal-B6 transgene activity in ALI cultures. Data are presented as mean \pm SEM. Columns with nonidentical superscript letters are significantly different $(P<0.05)$ as determined by analysis of variance using the Tukey postcomparison test. P2 to P4, proliferation days 2 to 4; ALI0 to ALI10, differentiation days 0 to 15. A: LEF1. B: TCF7. C: Myc. D: Axin2.

\section{Dynamic Pattern of WNT/ $\beta$-Catenin Pathway Gene Expression in Vitro}

The WNT/ $\beta$-catenin pathway target genes that were evaluated in vivo (Figure 2) were analyzed at various time points in ALI cultures. Lef1 was expressed on ALI days 0 to 7 but was not detected on proliferation days 2 or 4 or ALI days 9 and 15 (Figure 7A). Transcript levels were low relative to the tracheal tissue calibrator and were variable. This pattern was similar to that detected in vivo and placed Lef1 gene expression in the early to middle differentiation phase (ALI days 0 to 7). TCF7 was detected at all time points tested in the ALI system, but expression levels peaked on day 4 (Figure 7B). This pattern suggested that TCF7 was expressed in basal cells, which were the prevalent cell type during this stage (see Supplemental Figure S2, A and B, at http://ajp.amjpathol.org). Low levels of TCF7 were detected during the differentiation stage. This pattern was distinct from that detected in vivo. Differences in the expression patterns of Lef1 and TCF7 suggest that they differentially regulated the pattern of gene expression in the proliferation and differentiation phases of epithelial repair.

Myc mRNA was most abundant during the proliferation phase. Myc mRNA abundance peaked on culture days 2 and 3 but decreased when the growth factor-rich medium was replaced (Figure $7 C$ ). As the cultures differentiated, Myc mRNA was detected, but at reduced levels. These data further support a role for Myc in the proliferation phase. This pattern was distinct from that of other WNT/ $\beta$-catenin pathway targets (see later herein) and will be pursued in a later study.

The WNT/ $\beta$-catenin pathway regulator Axin 2 was detected at all time points tested in vitro (Figure 7D). Transcript abundance increased approximately fourfold between proliferation day 2 and ALI day 3 and persisted through ALI day 9. Detection of Axin 2 throughout the differentiation phase suggested that WNT/ $\beta$-catenin signaling occurred during this stage. The ALI pattern was distinct from that in the in vivo analysis, where significant changes in Axin 2 mRNA abundance were not detected (Figure 2D). These data suggest that analysis of the WNT/ $\beta$-catenin pathway in vivo was compromised by overlapping signaling processes.

\section{Genetic Stabilization of $\beta$-Catenin in Basal Cells in Vitro}

The ALI analysis suggested that WNT/ $\beta$-catenin regulated basal cell proliferation and differentiation. To evaluate the role of $\beta$-catenin in basal cell behavior, ALI cultures were generated from K14-rtTA/TRE-cre/DE3 (BiTg) mice. Western blot analysis of $\beta$-catenin in ALI day 5 cultures generated from BiTg or monotransgenic TRE-cre/DE3 cells demonstrated recombination of the $\beta$-catenin locus and generation of the mutant $\beta$-catenin (see Supplemental Figure S5 at http://ajp.amjpathol.org). This recombination was doxycycline independent. A sexual dimorphism related to the X-linked status of the K14rtTA transgene ${ }^{16}$ was noted. K14-rtTA/DE3 monotransgenic cells did not undergo recombination. To determine whether recombination ceased after the proliferation phase, ALI cultures from ALI days 0 to 10 were analyzed for $\beta$-catenin by Western blot analysis (see Supplemental Figure S6 at $h$ ttp://ajp.amjpathol.org). Quantification demonstrated that recombination occurred early and that the level of modified $\beta$-catenin did not change after day 5 . These results were confirmed by dual-immunofluorescence analysis of $\mathrm{N}$-and $\mathrm{C}$-terminal $\beta$-catenin as a func-

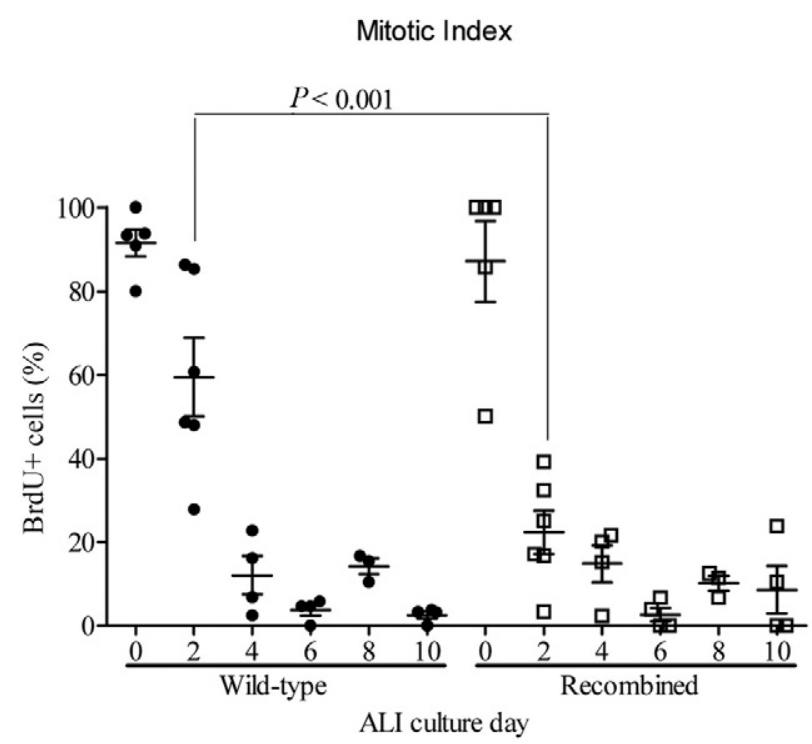

Figure 8. Stabilization of $\beta$-catenin shortens the proliferation stage in vitro. ALI cultures derived from K14/rtTA/TRE-cre/DE3 mice generated a mosaic epithelium composed of $\beta$-catenin wild-type and $\beta$-catenin-stabilized (recombined) regions. Mitotic activity was evaluated using BrdU pulse labeling. The number of BrdU+ cells is presented as a percentage of all cells in the region. Wild-type regions, solid circles; recombined regions, open squares. Data are presented as mean \pm SEM. Significance $(P<0.05)$ was determined by 2 -way analysis of variance using the Bonferroni postcomparison test. 


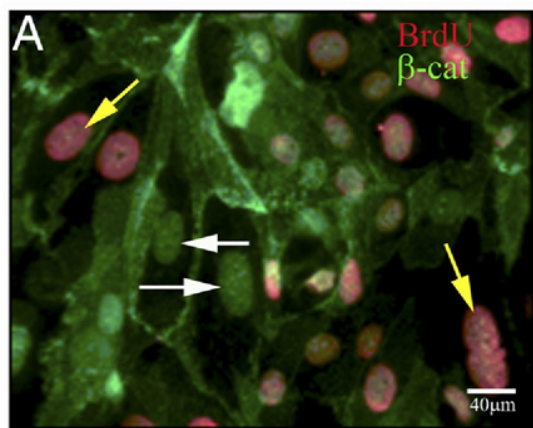

Subcellular Distribution of $\beta-$ Catenin
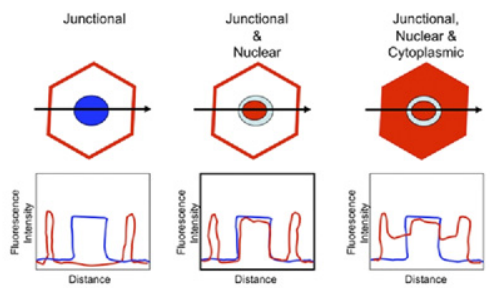

F

Wild-Type Cells

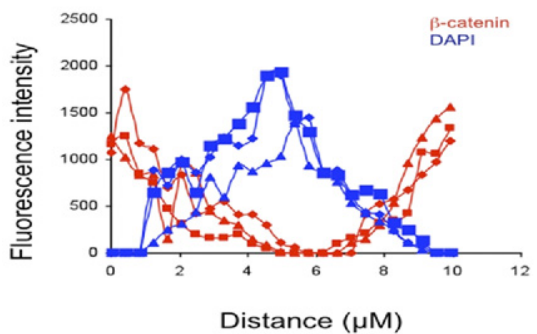

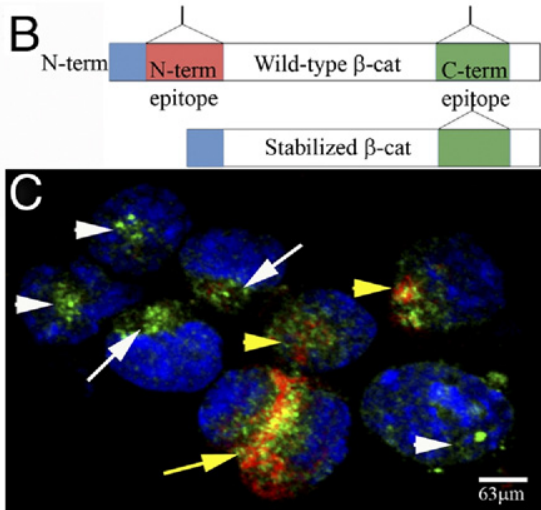

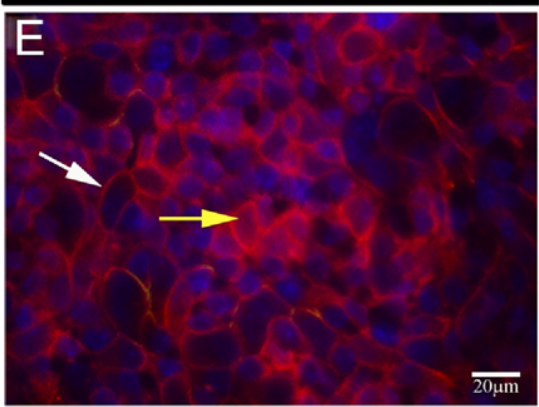

G Stabilized $\beta$-Catenin-Expressing Cells

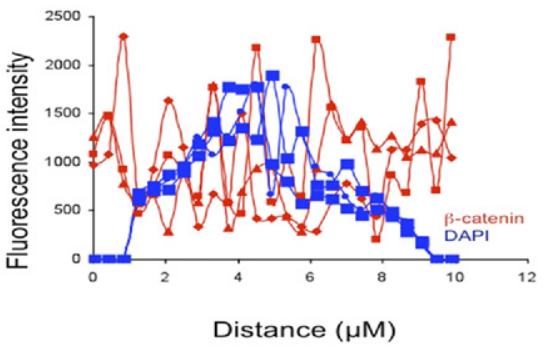

Figure 9. Cellular distribution of $\beta$-catenin Cells and cultures were derived from K14/rtTA/ tre-cre/DE3 mice. $\beta$-Catenin cellular distribution was evaluated by dual immunofluorescence on cells grown on glass coverslips, cytospins from ALI day 3 cultures, and confocal microscopy of ALI membranes. A: Cells grown on glass coverslips $\beta$-catenin ( $\beta$-cat; green) and $\operatorname{BrdU}$ (red). Yellow arrows demonstrate co-localization of $\beta$-catenin and BrdU. White arrows indicate cells with nuclear localized $\beta$-catenin in nonmitotic cells. B: Schematic of the K14/rtTA/tre-cre/ DE3-stabilized allele. Wild-type cells have alleles with both the N-terminal (N-term) and C-terminal (C-term) epitopes; therefore, they are labeled red and green when both antibodies are used for dual immunofluorescence. Stabilized cells do not have the N-terminal epitope and are, therefore, identified by single staining. C: Cytospins from ALI day 3 membranes. White arrowheads indicate localization of stabilized $\beta$-catenin (green only). Yellow arrowheads show wild-type cells with nuclear $\beta$-catenin (red and green). White arrows indicate stabilized cells with cytoplasmic $\beta$-catenin. Yellow arrows indicate wild-type cells with cytoplasmic $\beta$-catenin. D: Schematic diagram of fluorescence intensity as a function of $\beta$-catenin distribution. E: $\beta$-Catenin (red) and nuclear (blue) signal in stabilized and wild-type regions. White arrow indicates junctional $\beta$-catenin. Yellow arrow indicates nuclear and cytoplasmic $\beta$-catenin. F: $\beta$-Catenin distribution in wild-type regions. $\mathbf{G}$ : $\beta$-Catenin distribution in stabilized regions.

tion of time (data not shown). Clara-like and ciliated cells were not detected during the proliferation phase of culture. These data indicate that the BiTg model could be used in vitro to evaluate the impact of $\beta$-catenin stabilization in basal cells and secondary effects on basal to ciliated and basal to Clara-like cell differentiation.

\section{$\beta$-Catenin Signaling in Basal Cells Decreases the Mitotic Index}

ALI cultures generated from BiTg tracheal cells produced a mosaic epithelium. Regions that were wild type for at least one $\beta$-catenin allele were identified by reactivity with the anti-N-terminal $\beta$-catenin antibody (see Supplemental Figure S7 at http://ajp.amjpathol.org): these regions are termed wild type. Regions that had undergone recombination on both $\beta$-catenin alleles were identified by an absence of $\mathrm{N}$-terminal $\beta$-catenin immunofluorescent staining: these regions are termed stabilized. In general, the area of stabilized regions was less than that of wildtype regions. To determine whether this size difference was a consequence of proliferation, the mitotic index in wild-type and stabilized regions was compared
(Figure 8). The mitotic index did not vary between wildtype and stabilized regions on ALI days 0, 4, 6, 8, and 10. However, a significant difference was detected on ALI day 2. At this time point, the mitotic index in stabilized regions was approximately half that in wild-type regions. Analysis by 2-way analysis of variance indicated that this difference was a consequence of stabilizing $\beta$-catenin rather than a consequence of time. These data indicate that stabilization of $\beta$-catenin decreased the proliferation period by 1 day.

\section{Nuclear Localization of $\beta$-Catenin in $\beta$-Catenin-Stabilized Cells}

To determine whether $\beta$-catenin stabilization resulted in increased nuclear translocation, we used several histologic methods. Cells were grown in the presence of doxycycline on glass coverslips and were labeled for 6 hours with BrdU. Dual immunofluorescence demonstrated colocalization of $\beta$-catenin (green) and BrdU (red), providing direct evidence of nuclear $\beta$-catenin in stabilized cells (Figure 9A). However, cultures grown on glass coverslips are submerged and are limited by the fact that they 
cannot be differentiated. To confirm the presence of nuclear $\beta$-catenin in stabilized cells grown in ALI, cells from ALI day 3 were recovered by trypsinization, and cytospins were generated. Dual immunofluorescence and confocal imaging of cytospins demonstrated a diverse culture composed of stabilized (green) and wild-type (red) cells with nuclear and/or cytoplasmic localized $\beta$-catenin (Figure 9, B and C). This method was excellent for demonstrating the dynamic pattern of $\beta$-catenin in stabilized and wild-type cells grown in ALI conditions, but it was limited by the fact that cytospins resulted in loss of culture morphology.

To determine the extent of nuclear, junctional, and cytoplasmic $\beta$-catenin in ALI cultures, we used confocal microscopy to quantify the cellular distribution of $\beta$-catenin. The histogram function was used to compare fluorescence signal intensity for $\beta$-catenin (red) and DNA (blue) along the diameter of wild-type and stabilized cells (Figure 9D). In wild-type cells, $\beta$-catenin was highly enriched in junctional complexes (Figure 9, E and F). In contrast, in stabilized cells, $\beta$-catenin was increased in the cytoplasmic and nuclear compartments (Figure 9, D and $E$ ). These data indicate increased free $\beta$-catenin in cells with stabilized $\beta$-catenin and suggest an increase in availability of $\beta$-catenin for the regulation of gene expression.

\section{$\beta$-Catenin Signaling in Basal Cells Enhances Basal to Ciliated Cell Differentiation}

To determine whether $\beta$-catenin stabilization in basal cells effected their differentiation to ciliated cells, the number of ACT + cells in wild-type and stabilized regions was compared on differentiation day 3. At this time, lineage tracing studies demonstrated that all ciliated cells were derived from basal cells. ${ }^{23}$ On differentiation day 3 , ciliated cells were present in wild-type and stabilized regions (Figure 10A). The percentage of ciliated cells in wild-type regions was half that in stabilized regions (Figure 10E). Ciliated cell differentiation was also evaluated on day 13 , when ciliated cells are derived from basal and Clara-like cells. The percentage of ciliated cells increased twofold in wild-type regions between ALI days 3 and 13 but did not change significantly in stabilized regions. On ALI day 13, ciliated cells were twofold more abundant compared with in stabilized regions (Figure 10, $\mathrm{B}$ and $\mathrm{E})$. These data indicate that $\beta$-catenin stabilization in basal cells enhanced basal to ciliated cell differentiation.

\section{$\beta$-Catenin Signaling in Basal Cells Blocks Basal to Clara-Like Cell Differentiation}

To determine whether $\beta$-catenin stabilization in basal cells effected their differentiation to Clara-like cells, the number of CCSP+ cells in wild-type and stabilized regions was compared on ALI day 8, the first time point that Clara-like cells were reliably detected in these cultures. At this time point, Clara-like cells were located exclusively in wild-type regions (Figure 10C). Of cells in wild-type
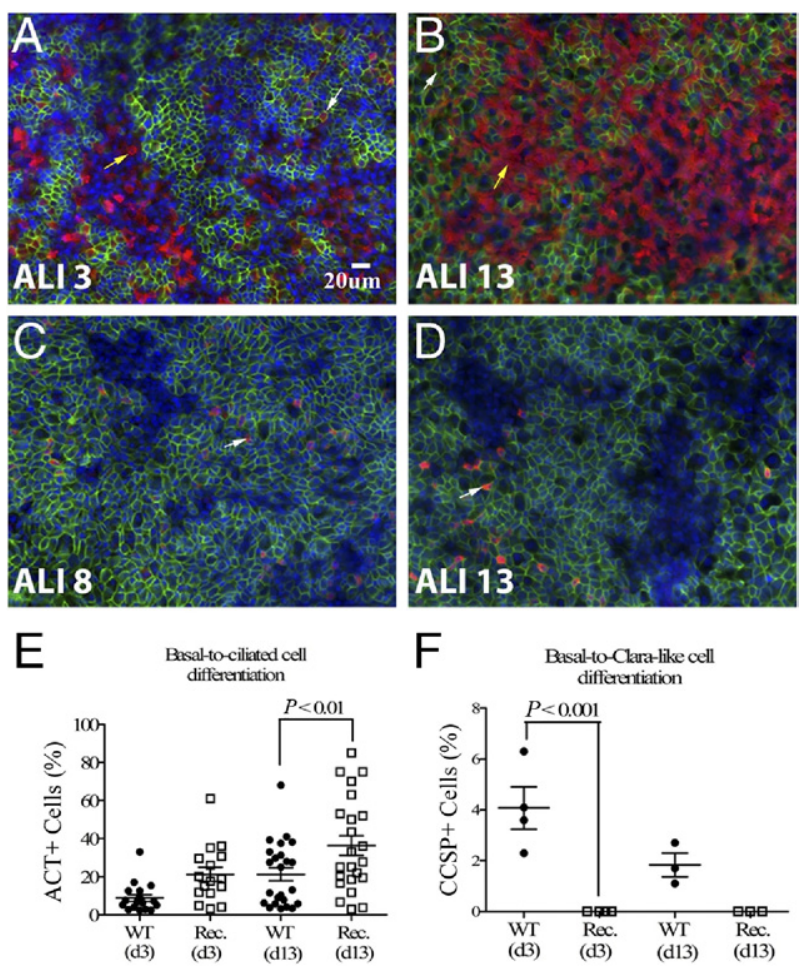

Figure 10. $\beta$-Catenin signaling in basal cells alters cell fate determination ALI cultures were derived from K14/rtTA/ter-cre/DE3 mice and were evaluated for basal to ciliated and basal to Clara-like cell differentiation using immunofluorescence. A-D: Dual immunofluorescence was used to analyze differentiation in ALI cultures. White arrows indicate cells of interest in wild-type regions. Yellow arrows indicate cells of interest in $\beta$-cateninstabilized regions. $\mathbf{E}$ and $\mathbf{F}$ : Number of cells expressing the differentiation markers ACT and CCSP is presented as a percentage of all cells in the region. Wild-type (WT) regions, closed circles; recombined (Rec.) regions, open squares. Data are presented as mean \pm SEM. Significance $(P<0.05)$ was determined by 2 -way analysis of variance using the Bonferroni postcomparison test. d 3 and d13, days 3 and 13. A: ALI day 3 ACT. B: ALI day 13 ACT. C: ALI day 8 CCSP. D: ALI day 13 CCSP. E: Quantification of ciliated cell differentiation. F: Quantification of Clara-like cell differentiation.

regions, $\sim 4 \%$ expressed CCSP (Figure 10F). No CCSP+ cells were detected in stabilized regions (Figure 10F). By differentiation day $13, \sim 2 \%$ of cells in wild-type regions expressed CCSP (Figure 10F). Stabilized regions remained devoid of the Clara-like cell type (Figure 10D). These results demonstrate that $\beta$-catenin stabilization blocked basal to Clara-like cell differentiation.

\section{Discussion}

The purpose of this study was to determine whether $\beta$-catenin regulated basal cell fate determination in the mouse trachea. In vivo analysis indicated a complex role for $\beta$-catenin in epithelial repair after NA injury. Use of tracheal epithelial ALI cultures permitted temporal separation of basal cell proliferation and basal cell differentiation into ciliated and Clara-like cells. Stabilization of $\beta$-catenin did not alter basal cell proliferation other than to shorten the proliferation phase by 1 day. Stabilization of $\beta$-catenin enhanced basal to ciliated cell differentiation twofold and was associated with a complete blockade of basal to Clara-like cell differentiation. These results sug- 
gest that $\beta$-catenin was a critical determinant of tracheal basal cell fate determination.

\section{Advantages and Disadvantages of the in Vitro Model}

The complexity of $\beta$-catenin signaling during injury and repair limited mechanistic analysis of $\beta$-catenin effects on basal cell proliferation and differentiation. We demonstrated that tracheal epithelial cell cultures recapitulate critical features of the NA injury and repair model but that they allow temporal segregation of proliferation and differentiation. In addition, this model partitions the basal to ciliated cell and basal to Clara-like cell replacement processes.

Injury and repair in vivo is a dynamic process involving several cell and tissue types that signal and respond to signals that alter the behavior of their environment and of the cells in that environment. The in vitro model is limited in its ability to recapitulate this complexity. The finding that basal cells generate numerous ciliated cells and fewer Clara-like cells may reflect this deficiency. However, consistent generation of Claralike cells indicates that the tracheal epithelial culture model is superior to the tracheosphere mode ${ }^{24}$ for analysis of Clara-like cell differentiation. Identification of a distinct Clara-like cell differentiation period permitted delineation of the role played by $\beta$-catenin in the generation of ciliated and Clara-like cells by basal cell progenitors.

\section{Roles for $\beta$-Catenin in Basal Cell Proliferation}

Accumulation of $\beta$-catenin in highly mitotic, rapidly renewing epithelium, such as the blood, intestine, and skin, results in stem cell proliferation and, when left unchecked, often results in the development of cancer and/or progression to metaplasia. ${ }^{25-28}$ Analysis of $\beta$-catenin-regulated cell function in these tissues has been facilitated by several naturally occurring mutations that impact progenitor cell function. ${ }^{29}$ However, the role of $\beta$-catenin stabilization in tissues with a low mitotic index and slow regeneration rates (eg, lung, liver, and pancreas) is less clear. ${ }^{7}$ The germ line mutations that severely alter progenitor cell proliferation and differentiation in the gut have little effect on the respiratory epithelium. These results suggest that $\beta$-catenin is a proximal regulator of cellular proliferation in some tissues, whereas it plays a more subtle role in the lung.

The $\beta$-catenin-TCF/LEF transcription complexes typically function as positive regulators of genes involved in progenitor cell proliferation, including Myc and cyclin D. ${ }^{30,31}$ Several cancers have mutations in the adenomatosis polyposis coli protein, resulting in overexpression of downstream $\beta$-catenin targets, such as Myc. Myc is widely recognized for its ability to promote cell proliferation by regulating cell cycle progression through $G(1)$ into $S$ phase. ${ }^{32,33}$ The present data demonstrate concurrent expression of Myc and stabilization of $\beta$-catenin in vivo and in vitro. Although compelling, cautious interpretation of the $\beta$-catenin-Myc pathway is required because proliferation was not strongly altered by $\beta$-catenin stabilization in vitro (Figures 6 and 7; see also Supplemental Figure S4 at $h$ ttp://ajp.amipathol.org) or in previous in vivo analyses. ${ }^{8,14}$ Thus, other signals, including growth factors, may function through or in parallel with $\beta$-catenin to regulate proliferation.

\section{Roles for $\beta$-Catenin in Basal to Ciliated Cell Differentiation}

Tracheal basal cells are the facultative progenitor pool. ${ }^{1}$ In the steady state, $\mathrm{K} 5+$ cells and the $\mathrm{K} 14$-expressing subset $^{23}$ maintain the basal cell pool. After NA injury, $\mathrm{K} 14+$ basal cells serve as a progenitor for ciliated and Clara-like cells. ${ }^{3,4}$ The direct differentiation of basal cells to ciliated cells ${ }^{23}$ is similar to the progenitor-progeny relationships reported for the adult human bronchial epithelial cells ex vivo ${ }^{5,6}$ and for the developing human and mouse lung (reviewed by Daniely et $\mathrm{al}^{34}$ ). A second cohort of ciliated cells is generated from the Clara-like cell progenitor in adult mice ${ }^{35}$ and rats. ${ }^{2}$

Several studies have reported activation of $\beta$-catenin reporter genes during the period of lung development in which basal cells are the sole source of ciliated cells (reviewed by De Langhe and Reynolds ${ }^{11}$ ). These data associated basal to ciliated cell differentiation with $\beta$-catenin signaling but did not establish cause and effect. The present analysis of ciliated cell differentiation demonstrated that $\beta$-catenin stabilization in basal cells increased ciliated cell differentiation. Minimally, this study demonstrated that basal to ciliated cell differentiation was not inhibited by excess $\beta$-catenin. The increase in ciliated cell differentiation may be a consequence of $\beta$-catenindependent promotion of basal to ciliated cell differentiation. However, an alternative explanation could be that $\beta$-catenin inhibited Clara-like cell differentiation. In this scenario, the pool of basal cell progenitors available to become ciliated cells would be increased. Differentiating between these two possible mechanisms requires further evaluation.

\section{Roles for $\beta$-Catenin in Basal to Clara-Like Cell Differentiation}

Analysis of $\beta$-catenin reporter transgene expression during lung development suggests a reciprocal relationship between $\beta$-catenin-dependent gene expression and differentiation of Clara-like and Clara cells. ${ }^{8}$ This observation was refined to a "just right" paradigm by the finding that low $\beta$-catenin signaling was important for Clara cell maturation but that deletion of the $\beta$-catenin signal after establishment of the prenatal Clara cell population did not alter the maturation process. ${ }^{14}$ These data suggested that $\beta$-catenin was critical for maintenance of an embryonic Clara cell progenitor but that $\beta$-catenin was not a positive mediator of the differentiation program. The present study supports this view by demonstrating a similar just right paradigm in the in vitro model. 
ALI cultures expressing wild-type levels of $\beta$-catenin underwent basal to Clara-like cell differentiation in the presence of $\beta$-catenin signaling as identified by expression of the TOPGal transgene. These data indicate that $\beta$-catenin signaling is permissive for Clara-like cell differentiation. Regions in the mosaic cultures that expressed at least one wild-type $\beta$-catenin allele produced Claralike cells, a result comparable with cultures expressing only wild-type $\beta$-catenin. However, the regions that expressed only stabilized $\beta$-catenin did not generate Claralike cells. The loss of basal to Clara-like cell differentiation may be the result of too much or prolonged $\beta$-catenin signaling. In either case, the just right hypothesis is supported by the results.

\section{Differential $\beta$-Catenin Signaling in Ciliated and Clara-Like Cells}

The differential effect of $\beta$-catenin on the generation of basal cell-derived differentiated cells begs the question of whether ciliated and Clara-like cells have distinct mechanisms to regulate $\beta$-catenin availability. Recent evidence indicates that Chibby is a potent inhibitor of $\beta$-catenin activity. Chibby regulates nuclear partitioning and $\beta$-catenin-dependent signaling via direct binding and nuclear export of $\beta$-catenin. ${ }^{36-38}$ The nuclear to cytoplasmic shuttling of $\beta$-catenin via Chibby uses interactions with $14-3-3$ zeta. ${ }^{38}$ Chibby is abundant in ciliated cells but is absent in Clara-like cells (data not shown). It is possible that the blockade of Clara-like cell differentiation in the presence of stabilized $\beta$-catenin is due to the inability of this cell type to export $\beta$-catenin via the Chibby-14-3-3 pathway. It is unlikely that increased $\beta$-catenin dose was toxic to the Clara-like cell because survival and proliferation of bronchial Clara cells that expressed stabilized $\beta$-catenin were not different from those of wild-type cells. In contrast, expression of Chibby in ciliated cells may give this cell type a competitive advantage and may result in ciliated cell hyperplasia.

\section{Clinical Relevance}

Many upper respiratory tract diseases are the result of defective wound repair. ${ }^{39}$ Repair of the TBE, as modeled by NA injury in mice, is a two-part wound-healing process. Basal cells proliferate for the purpose of reepithelialization and then differentiate to reestablish a functional secretory/ciliated epithelium. Disruption of the TBE is a common pathologic alteration that is observed in numerous chronic lung diseases, including cystic fibrosis, asthma, chronic obstructive pulmonary disease, bronchopulmonary dysplasia, and idiopathic pulmonary fibrosis. ${ }^{40}$ Cellular alterations in the TBE lesion include basal cell hyperplasia and secretory and ciliated cell hypoplasia. In idiopathic pulmonary fibrosis, this abnormality is associated with reactivation of the embryonic signaling pathway $W n t / \beta$-catenin pathway. ${ }^{41}$ The present study supports the hypothesis that the activation of $\beta$-catenin in the human TBE alters basal cell fate determination. An understanding of the basal cell lineage and the role of $\beta$-catenin in the selection of ciliated versus Clara-like cell fate is an important clue to understanding the cellular and molecular underpinnings of airway disease and may be the basis for redirection of basal cell differentiation toward normal cellular phenotypes.

\section{Acknowledgments}

We thank Dr. Steve Brody (University of Washington, St. Louis, MO) for assistance with the ALI method, Fluidigm Corp. (San Francisco, CA) for assistance with gene expression analysis, and Elena Reynolds for assistance with morphometry.

\section{References}

1. Cole BB, Smith RW, Jenkins KM, Graham BB, Reynolds PR, Reynolds SD: Tracheal basal cells: a facultative progenitor cell pool. Am J Pathol 2010, 177:362-376

2. Evans MJ, Shami SG, Cabral-Anderson LJ, Dekker NP: Role of nonciliated cells in renewal of the bronchial epithelium of rats exposed to $\mathrm{NO}_{2}$. Am J Pathol 1986, 123:126-133

3. Hong KU, Reynolds SD, Watkins S, Fuchs E, Stripp BR: Basal cells are a multipotent progenitor capable of renewing the bronchial epithelium. Am J Pathol 2004, 164:577-588

4. Hong KU, Reynolds SD, Watkins S, Fuchs E, Stripp BR: In vivo differentiation potential of tracheal basal cells: evidence for multipotent and unipotent subpopulations. Am J Physiol Lung Cell Mol Physiol 2004, 286:L643-L649

5. Engelhardt JF, Allen ED, Wilson JM: Reconstitution of tracheal grafts with a genetically modified epithelium. Proc Natl Acad Sci U S A 1991, 88:11192-11196

6. Engelhardt JF, Schlossberg H, Yankaskas JR, Dudus L: Progenitor cells of the adult human airway involved in submucosal gland development. Development 1995, 121:2031-2046

7. Stripp BR, Reynolds SD: Maintenance and repair of the bronchiolar epithelium. Proc Am Thorac Soc 2008, 5:328-333

8. Reynolds SD, Zemke AC, Giangreco A, Brockway BL, Teisanu RM Drake JA, Mariani T, Di PY, Taketo MM, Stripp BR: Conditional stabilization of $\beta$-catenin expands the pool of lung stem cells. Stem Cells 2008, 26:1337-1346

9. Dean CH, Miller LA, Smith AN, Dufort D, Lang RA, Niswander LA Canonical Wnt signaling negatively regulates branching morphogenesis of the lung and lacrimal gland. Dev Biol 2005, 286:270-286

10. Okubo T, Hogan BL: Hyperactive Wnt signaling changes the developmental potential of embryonic lung endoderm. J Biol 2004, 3:11

11. De Langhe SP, Reynolds SD: Wnt signaling in lung organogenesis. Organogenesis 2008, 4:100-108

12. Li C, Li A, Li M, Xing Y, Chen H, Hu L, Tiozzo C, Anderson S, Taketo MM, Minoo P: Stabilized $\beta$-catenin in lung epithelial cells changes cell fate and leads to tracheal and bronchial polyposis. Dev Biol 2009, 334:97-108

13. Harada N, Tamai Y, Ishikawa T, Sauer B, Takaku K, Oshima M, Taketo MM: Intestinal polyposis in mice with a dominant stable mutation of the $\beta$-catenin gene. EMBO J 1999, 18:5931-5942

14. Zemke AC, Teisanu RM, Giangreco A, Drake JA, Brockway BL, Reynolds SD, Stripp BR: $\beta$-Catenin is not necessary for maintenance or repair of the bronchiolar epithelium. Am J Respir Cell Mol Biol 2009, 41:535-543

15. DasGupta R, Fuchs E: Multiple roles for activated LEF/TCF transcription complexes during hair follicle development and differentiation. Development 1999, 126:4557-4568

16. Xie W, Chow LT, Paterson AJ, Chin E, Kudlow JE: Conditional expression of the ErbB2 oncogene elicits reversible hyperplasia in stratified epithelia and up-regulation of TGF $\alpha$ expression in transgenic mice. Oncogene 1999, 18:3593-3607 
17. Perl AK, Wert SE, Nagy A, Lobe CG, Whitsett JA: Early restriction of peripheral and proximal cell lineages during formation of the lung Proc Natl Acad Sci U S A 2002, 99:10482-10487

18. You Y, Richer EJ, Huang T, Brody SL: Growth and differentiation of mouse tracheal epithelial cells: selection of a proliferative population. Am J Physiol Lung Cell Mol Physiol 2002, 283:L1315-L1321

19. Heid CA, Stevens J, Livak KJ, Williams PM: Real time quantitative PCR. Genome Res 1996, 6:986-994

20. Tenu JP, Viratelle OM, Garnier J, Yon J: pH dependence of the activity of $\beta$-galactosidase from Escherichia coli. Eur J Biochem 1971, 20:363-370

21. Repouskou A, Sourlingas TG, Sekeri-Pataryas KE, Prombona A: The circadian expression of c-MYC is modulated by the histone deacetylase inhibitor trichostatin $A$ in synchronized murine neuroblastoma cells. Chronobiol Int 27:722-741

22. Wee KB, Surana U, Aguda BD: Oscillations of the p53-Akt network: implications on cell survival and death. PLoS One 2009, 4:e4407

23. Ghosh M, Brechbuhl HM, Smith RW, Li B, Hicks DA, Titchner T, Runkle CM, Reynolds SD: Context-dependent differentiation of multipotential keratin 14-expressing tracheal basal cells. Am J Respir Cell Mol Biol 2010, [Epub ahead of print]

24. Rock JR, Onaitis MW, Rawlins EL, Lu Y, Clark CP, Xue Y, Randell SH, Hogan BL: Basal cells as stem cells of the mouse trachea and human airway epithelium. Proc Natl Acad Sci U S A 2009, 106:12771-12775

25. Breuhahn K, Singh S, Schirmacher P, Blaker H: Large-scale N-terminal deletions but not point mutations stabilize $\beta$-catenin in small bowe carcinomas, suggesting divergent molecular pathways of small and large intestinal carcinogenesis. J Pathol 2008, 215:300-307

26. Guo Z, Dose M, Kovalovsky D, Chang R, O'Neil J, Look AT, von Boehmer $\mathrm{H}$, Khazaie K, Gounari F: $\beta$-Catenin stabilization stalls the transition from double-positive to single-positive stage and predisposes thymocytes to malignant transformation. Blood 2007, 109:5463-5472

27. Rubinfeld B, Robbins P, El-Gamil M, Albert I, Porfiri E, Polakis P: Stabilization of $\beta$-catenin by genetic defects in melanoma cell lines. Science 1997, 275:1790-1792

28. Gat U, DasGupta R, Degenstein L, Fuchs E: De Novo hair follicle morphogenesis and hair tumors in mice expressing a truncated $\beta$-catenin in skin. Cell 1998, 95:605-614
29. Clevers H: Wnt breakers in colon cancer. Cancer Cell 2004, 5:5-6

30. He TC, Sparks AB, Rago C, Hermeking H, Zawel L, da Costa LT, Morin PJ, Vogelstein B, Kinzler KW: Identification of c-MYC as a target of the APC pathway. Science 1998, 281:1509-1512

31. Takayama S, Rogatsky I, Schwarcz LE, Darimont BD: The glucocorticoid receptor represses cyclin D1 by targeting the Tcf- $\beta$-catenin complex. J Biol Chem 2006, 281:17856-17863

32. Prochownik EV: c-Myc: linking transformation and genomic instability. Curr Mol Med 2008, 8:446-458

33. Wang H, Mannava S, Grachtchouk V, Zhuang D, Soengas MS, Gudkov AV, Prochownik EV, Nikiforov MA: c-Myc depletion inhibits proliferation of human tumor cells at various stages of the cell cycle. Oncogene 2008, 27:1905-1915

34. Daniely Y, Liao G, Dixon D, Linnoila RI, Lori A, Randell SH, Oren M, Jetten AM: Critical role of p63 in the development of a normal esophageal and tracheobronchial epithelium. Am J Physiol Cell Physiol 2004, 287:C171-C181

35. Rawlins EL, Hogan BL: Epithelial stem cells of the lung: privileged few or opportunities for many? Development 2006, 133:2455-2465

36. Li FQ, Mofunanya A, Fischer V, Hall J, Takemaru K: Nuclear-cytoplasmic shuttling of Chibby controls $\beta$-catenin signaling. Mol Biol Cell 2010, 21:311-322

37. Li FQ, Mofunanya A, Harris K, Takemaru K: Chibby cooperates with 14-3-3 to regulate $\beta$-catenin subcellular distribution and signaling activity. J Cell Biol 2008, 181:1141-1154

38. Takemaru K, Fischer V, Li FQ: Fine-tuning of nuclear-catenin by Chibby and 14-3-3. Cell Cycle 2009, 8:210-213

39. Gardner A, Borthwick LA, Fisher AJ: Lung epithelial wound healing in health and disease. Expert Rev Respir Med 2010, 4:647-660

40. Rock JR, Randell SH, Hogan BL: Airway basal stem cells: a perspective on their roles in epithelial homeostasis and remodeling. Dis Model Mech 2010, 3:545-556

41. Chilosi M, Poletti V, Zamo A, Lestani M, Montagna L, Piccoli P, Pedron S, Bertaso M, Scarpa A, Murer B, Cancellieri A, Maestro R, Semenzato G, Doglioni $\mathrm{C}$ : Aberrant Wnt/ $\beta$-catenin pathway activation in idiopathic pulmonary fibrosis. Am J Pathol 2003, 162:1495-1502 